\title{
ОСОБЛИВОСТІ РЕФЛЕКСИВНИХ ПРОЦЕСІВ ОСІБ ІЗ РІЗНИМ ТІЛЕСНИМ ДОСВІДОМ У КОНТЕКСТІ САМОПРОЕКТУВАННЯ
}

\author{
Удк: 159.9
}

\author{
Колярова Анастасія Олегівна \\ Аспірантка Інституту психології імені \\ Г. С. Костюка Національної академії педагогіч- \\ них наук Украӥни, м. Київ (Украӥна) \\ ORCID ID: https://orcid.org/0000-0002-4329-1413
}

\begin{abstract}
Анотація. Стаття присвячена з'ясуванню особливостей різних видів рефлексивних проиесів осіб, які за відмінних життєвих обставин отримали тілесний досвід. Зокрема, у статті визначено вплив тих чи інших рефлексивних процесів на розвиток здатності до самопроектування особистості. Дослідження проведено на емпірично сформованих вибірках, щзо характеризуються різними комбінаціями сформованих видів рефлексіі. За результатами аналізу спонукальних $і$ блокувальних впливів різновидів рефлексивних прочесів на розвиток здатності до самопроектування особистості виділено конструктивний та неконструктивний рефлексивні стилі особистості. Встановлено, щуо конструктивні рефлексивні стилі включають позитивну системну рефлексію. Неконструктивні рефлексивні стилі блокують процес розвитку здатності до самопроектування особистості та мають два підвиди: неконструктивний рефлексивний стиль із включеними квазірефлексивними прочесами; неконструктивний рефлексивний стиль із несформованою позитивною рефлексією.
\end{abstract}

Ключові слова: рефлексія, рефлексивний стиль особистості, тілесний досвід, самопроектування особистості.

Постановка проблеми. Самопроектування особистості базується на розумінні та інтерпретації набутого соціокультурного та особистого досвіду шляхом занурення в дискурсивний простір i, на цій основі, створення власного смислового простору. Тілесний досвід $є$ первинним досвідом особистості та задає базові орієнтири для розуміння й вибудовування особистістю самої себе, власної життєвої траєкторії життєздійснення, та становить основу для інших, більш складних, форм досвіду особистості. У складному та багатоаспектному процесі перетворення особистого досвіду на особистісний (Н. В. Чепелєва) важливу 
роль відіграє рефлексія як провідний механізм самопізнання та саморозвитку особистості. Залежно від типу спрямованості процесів усвідомлення на власний тілесний досвід рефлексивний стиль особистості може набирати конструктивних або неконструктивних характеристик для процесу самопроектування особистості. Отже, вивчення особливостей рефлексії тілесного досвіду проливає світло на процес самопроектування особистості в ціломy.

Тому, метою даного дослідження є з'ясування особливостей рефлексивних процесів осіб із різним тілесним досвідом у контексті самопроектування особистості. Для досягнення поставленої мети необхідно вирішити наступні послідовні завдання:

1. На основі емпіричного дослідження сформувати вибірки, які характеризуються різними комбінаціями видів рефлексії.

2. Визначити особливості розвитку здатності до самопроектування особистості в осіб 3 різними видами рефлексивних процесів.

3. 3'ясувати характер впливу різних видів рефлексивних процесів на розвитку здатності до самопроектування особистості.

4. Визначити рефлексивні стилі особистості осіб, які мають тілесний досвід, у контексті самопроектування особистості.

Аналіз досліджень 3 проблеми. До концептуальних засад дослідження проблем тілесного досвіду особистості в психології можна віднести положення про тілесність як детермінанту життєвого самовизначення особистості (А. Рождественський), про внутрішню психологічну структуру та зміст тілесності (Д. Бескова, С. Рупчев), про тілесність як внаслідок соціокультурного визначення (А. Тхостов, І. Журавльов) і опосередкування змістом (В. Зінченко). Значна кількість досліджень присвячено різним складовим тілесного досвіду особистості (А. Дорожевець, А. Мотовилін, А. Соколова, Р. Берні, А. Соколова, В. Мухіна, І. Чеснокова, І. Кон, О. Тхостов, А. Налчаджян та ін.). Втім, вивченню особливостей рефлексії тілесного досвіду у процесі самопроектування особистості 3 погляду психолого-герменевтичного підходу не приділено достатньої уваги.

Тілесний досвід рефлексується далеко не усіма індивідами [3]. Тож, з метою емпіричного дослідження особливостей різних видів рефлексивних процесів у здатності особистості до самопроектування було сформовано вибірку із осіб, які набуваючи життєвого досвіду, в силу різних обставин (професійних, мотиваційних, стану здоров'я тощо) отримали й тілесний досвід та є, принаймні потенційно, здатними до самопроектування власної особистості.

Виклад основного матеріалу. У здатності особистості до самопроектування як складному багаторівневому утворенні ядерною складовою $є$ інтегральний корпус психологічних характеристик особистості, серед яких визначаються наступні: самоставлення, 
яке основується на самопізнанні, самоосмисленні та самовизначенні; суб'єктивний контроль як показник рівня самодетермінованості особистості; смисложиттєві орієнтації як результат смислотворення та життєтворення особистості; перспективна орієнтованість індивідуального досвіду особистості. Для кожного із визначених чинників підібрано відповідні методики опитування: опитувальник самоставлення С. Р. Пантілєєва; модифікований варіант тесту-опитувальника «Рівень суб'єктивного контролю» Дж. Роттера; тест смисложиттєвих орієнтацій Д. О. Леонтьєва; модифікована методика провокованого наративу «Моя особистість» О. В. Зазимко. Види реф- ксія) і негативні (інтроспекція, квазірефлексія) різновиди рефлексивних процесів [1]. Автори стверджують, що системна рефлексія $є$ найбільш адаптивною, і саме ця форма пов'язана із самодетермінацією особистості.

Вибірка досліджуваних, які у тих чи інших життєвих умовах здобули тілесний досвід, за рівнями різних видів рефлексивних процесів розподілилась нерівномірно. Частотний аналіз показує, що у досліджуваних осіб сформована не лише адаптивна системна рефлексія, хоча ій належить найбільша частка (Табл. 1). Більша частина досліджуваних має певні комбінації сформованих видів рефлексії.

Майже у половини досліджуваних

Таблиия 1.

Частота прояву рівнів сформованості видів рефлексії

\begin{tabular}{|c|c|c|c|c|}
\hline \multicolumn{2}{|c|}{$\begin{array}{l}\text { Частота прояву рівнів / Вид реф- } \\
\text { лексії }\end{array}$} & \multirow{2}{*}{$\begin{array}{c}\text { Системна } \\
178\end{array}$} & \multirow{2}{*}{$\frac{\text { Інтроспективна }}{143}$} & \multirow{2}{*}{$\frac{\text { Квазірефлексія }}{110}$} \\
\hline Рівень сформо- & кількість осіб & & & \\
\hline рефлексії & відсоток & 89,0 & 71,5 & 55,0 \\
\hline \multirow{2}{*}{$\begin{array}{c}\text { Рівень несфор- } \\
\text { мованості виду } \\
\text { рефлексії } \\
\end{array}$} & кількість осіб & 22 & 57 & 90 \\
\hline & відсоток & 11,0 & 28,5 & 45,0 \\
\hline \multirow{2}{*}{ Всього } & кількість осіб & 200 & 200 & 200 \\
\hline & відсоток & 100,0 & 100,0 & 100,0 \\
\hline
\end{tabular}

лексивних процесів виявлено за допомогою методики диференційної діагностики рефлексивності (ДДР) Д. Леонтьєва і С. Осіна. Результати дослідження піддано математичному та якісному аналізу.

Опитувальник ДДР створено на основі диференційної моделі рефлексивності, за якою розрізняють позитивну (системна рефле-
(44,5 \%) сформовані всі три види рефлексії. У четвертої частини досліджуваних (24\%) не сформована лише квазірефлексія. I лише у 14 \% досліджуваних сформована системна рефлексія без інших негативних рефлексивних процесів.

Слід зазначити, що сформованість лише одного інтроспективного виду рефлексії як 
самокопання, не виявилась у жодного досліджуваного. Можемо припустити, що особи, які мають той чи інший тілесний досвід та здатність до самопроектування, не зосереджуються виключно на власному стані, власних переживаннях, особистісних характеристиках, тобто не схильні виключно до глибокого самокопання. Наше припущення підтверджується й дослідженнями авторів методики [1, c. 117].

Втім, сформованість лише одного виду непродуктивної рефлексії - квазірефлексії, відстежується у 2 \% досліджуваних. Всі ці досліджувані (4 особи) у минулому були професійними спортсменами. Отримання тілесної травми, змусило їх відмовитися від професійної кар'єри. Як зазначають розробники опитувальника, квазірефлексія негативно корелює 3 контролем за діями при невдачі (Ю. Куль) та пов'язана з відривом від актуальної життєвої ситуації. Мабуть, для осіб, які раніше чітко вбачали перспективу власної спортивної кар'єри, квазірефлексивні процеси стали захисними механізмами на шляху успішної реабілітації після травм.

У 6,5 \% досліджуваних відстежується несформованість жодного виду рефлексії, ці особи належать до усіх чотирьох діагностованих вибірок.

Подальше дослідження особливостей рефлексивних процесів у здатності особистості до самопроектування особистості проведено на шести емпірично створених вибірках, які розрізняються за сформованими різновидами рефлексивних процесів. Кожній із цих вибірок присвоєно код:

«позитивна рефлексія» - вибірка осіб, у яких сформована лише позитивна (системна) рефлексія, складається із 28 осіб; «усі види рефлексї» - сформовані всі види рефлексивних процесів (89 осіб);

«позитивна + інтроспекиія» - сформовані системні та інтроспективні рефлексивні процеси (49 осіб);

«позитивна + квазірефлексія» - сформовані системні та квазірефлексивні процеси (12 осіб);

«негативна рефлексія» - сформовані лише негативні рефлексивні процеси (9 осіб); «несформована рефлексія» - рефлексивні процеси сформовані на низькому рівні (13 осіб).

Здатність до самопроектування особистості визначено за означеними вище методиками. Встановлення міжгрупових відмінностей проведено за допомогою реалізації статистичного тесту U - критерія Манна-Вітні при попарному порівнянні всіх шести вибірок.

Статистично визначені відмінності за результатами дослідження самоставлення дозволили охарактеризувати особливості вибірок з різними рефлексивними процесами.

Особи 3 вибірки «позитивна рефлексія» $є$ більш схильними до глибоких сумнівів в унікальності власної особистості, недооцінки свого духовного «Я» у порівнянні з особа- 
ми 3 вибірки «усі види рефлексії». Маючи сформовану лише позитивну рефлексію, особи характеризуються підвищеною чутливістю до зауважень і критики оточуючих на свою адресу, що робить їх більш ранимими і схильними не довіряти власній індивідуальності на противагу тим особам, у яких сформовані всі виділені види рефлексивних процесів. Тобто, досліджувані з вибірки «усі види рефлексії» $\epsilon$ більш ригідними у власному саморозвитку (шкала «Самоцінність»).

Особи 3 вибірки «усі види рефлексії», на противагу тим, у кого сформований лише іï позитивний вид, більш вище оцінюють свій духовний потенціал, багатство свого внутрішнього світу, власну неповторність (шкала «Самоцінність»). Значно відрізняються вони i від тих осіб, у яких не сформований якийсь із видів негативної рефлексії за наступними характеристиками. Порівняно 3 вибіркою «позитивна + інтроспекція», тобто з тими особами, у яких не сформовані квазірефлексивні процеси, більш схильні сприймати себе принятими оточуючими людьми, більш схильні відчувати, що їх люблять, цінять за особистісні та духовні якості, за здійснені вчинки і дії тощо, більш яскраво відчувають власну емоційну відкритість у взаємодії з іншими (шкала «Відзеркалене самоставлення»), а також, більш високо оцінюють власну індивідуальність, неповторність, багатство внутрішнього світу (шкала «Самоцінність»). Встановлені також значимі відмінності й від осіб, які вхо- дять до вибірки «негативна рефлексія», у яких не сформована позитивна системна рефлексія, а саме, вони є більш відкритими новому досвіду пізнання себе, вирізняються більшою готовністю до змін власної «Я-концепції», що сприяє більш легкій зміні уявлень про себе, причиною чого може бути незадоволеність собою (шкала «Самоприхильність»).

Вибірка «негативна рефлексія», у свою чергу, значно відрізняється від вибірок «усі види рефлексії» та «позитивна + інтроспекція» більш вищою ригідністю «Я»-концепції, прагненням зберігати в сталому стані свої якості, вимоги до себе та бачення й оцінку себе, тобто більш виражено відчувають власну самодостатність, що не сприяє реалізації можливості саморозвитку і самовдосконалення. У них можуть яскравіше проявлятися особистісна тривожність, схильність сприймати оточуючий світ як загрозу для самооцінки, що є завадами на шляху саморозкриття (шкала «Самоприхильність»).

Особи, з вибірки «несформована рефлексія» значно вирізняються на фоні осіб 3 вибірки «позитивна + інтроспекція». Перші характеризуються більш яскраво вираженим сприйняттям себе такими, яких люблять і цінують, відчуттям власної більш вищої комунікабельності, емоційної відкритості для взаємодії з іншими, легкості встановлення ділових i особистісних контактів (шкала «Відзеркалене самоставлення») та, на фоні відчуття власної самодостатності, більш ви- 
щим прагненням залишатися такими як $є$, що не сприяє реалізації можливості саморозвитку та самореалізації (шкала «Самоприхильність»).

Слід ще зазначити значимі відмінності між вибірками «позитивна + інтроспекція» та «позитивна + квазірефлексія». Особи, у яких сформовані інтроспективні рефлексивні процеси більш сумніваються в унікальності власної особистості, мають більш високу чутливість до критики від оточуючих. Особи, у яких сформовані квазірефлексивні процеси більш впевнені у власній індивідуальності та більш стійкі до впливів середовища (шкала «Самоцінність»).

Таким чином, можна зробити висновок, що несформованість позитивного виду рефлексії (системної рефлексії) є менш сприятливою умовою для самопроектування та саморозвитку особистості. Особи 3 негативними видами рефлексії та взагалі 3 несформоваю рефлексією є більш суб'єктивно впевнені у власній самодостатності (шкала «Самоцінність») та позитивному сприйнятті їх з боку оточуючих (шкала «Відзеркалене самоставлення»), що понижує рівень бажання змінюватись стосовно наявного стану (шкала «Самоприхильність»). У випадку порівняння поєднання позитивного виду рефлексії з іншим одним негативним, спостерігається сильний прояв захисної функції «Я» при квазірефлексивних процесах. Тобто, можна передбачити, що поєднання позитивної рефлексії з квазі- рефлексією може бути блокуючою умовою для саморозвитку та самоздійснення особистості.

Попарне порівняння вибірок за особливостями суб'єктивного контролю як показника рівня самодетермінованості особистості вказало на відмінності вибірок лише за двома шкалами теста-опитувальника «рівень суб'єктивного контролю» (РСК) Дж. Роттера: «інтернальності у сфері міжособистісних стосунків», «інтернальності у сфері досягнень». 3 чого можна зробити висновок, що як загальна інтернальність осіб, які мають тілесний досвід, так і її прояви у більшості життєвих ситуаціях (у сфері невдач, сімейних і виробничих стосунках та стосовно ставлення до власного здоров'я і хвороби) не залежать від виду рефлексивних процесів.

За «Шкалою інтернальності у сфері досягнень» вибірка «позитивна + квазірефлексія» відрізняється від вибірок «усі види рефлексії» $(\mathrm{p} \leq 0,01)$ та «позитивна + інтроспекція» $(\mathrm{p} \leq 0,01)$. Отже, відсутність сформованих інтроспективних рефлексивних процесів дозволяє припускати таким досліджуваним, що всього того, що вони вважають емоційно позитивними подіями, вони досягли самі, та, що вони здатні з успіхом іти до наміченої мети в майбутньому. Особи із вибірок, у яких сформовані системні та інтроспективні рефлексивні процеси, складовими успіху досягнень певних результатів визначають також і зовнішні обставини, доленосні події та допомогу ін- 
ших.

За «Шкалою інтернальності у сфері міжособистісних стосунків» вибірка «позитивна рефлексія» відрізняється від вибірок «несформована рефлексія» (p $\leq 0,01)$ та «позитивна + інтроспекція» $(\mathrm{p} \leq 0,01)$. Встановлені відмінності вказують на те, що особи 3 вибірки «позитивна рефлексія» відчувають себе більш здатними викликати повагу і симпатію інших людей, ніж особи, у яких не сформовані ніякі рефлексивні процеси, чи особи, які мають сформовану позитивну рефлексію в сукупності 3 негативними інтроспективними рефлексивними процесами. Втім, встановлені ще й значимі відмінності за цією шкалою i між вибірками «позитивна + інтроспекція» $(\mathrm{p} \leq 0,05)$ та «позитивна + квазірефлексія» $(\mathrm{p} \leq 0,05)$, причому саме особи з останньої вибірки більш схильні відчувати себе такими, яких поважають і оцінюють як приємних людей, на відміну від осіб 3 вибірки «позитивна + інтроспекція», які більш схильні не брати на себе відповідальність за власні стосунки з оточуючими.

Таким чином, можемо констатувати очевидний факт, що позитивна рефлексія сприяє інтернальності у сфері міжособистісних стосунків. Проте, поєднання одночасно сформованого системного та якогось одного із видів негативних рефлексивних процесів призводить до неадекватного оцінювання власних зусиль у встановленні міжособистісних стосунків. При сформованих позитивній та інтрос- пективній рефлексії, особи не схильні брати на себе відповідальність за всілякі негаразди в особистісних стосунках з іншими людьми, а при сформованих позитивній та квазірефлекції, особи схильні не помічати несимпатизуючого до них відношення.

За опитувальником смисложиттєвих орієнтацій не встановлено жодних статистично достовірних міжгрупових відмінностей. Отже, сформованість того чи іншого виду рефлексії в осіб, які мають тілесний досвід, не відбиваються на уявленнях про смисложиттєві орієнтації власного життя.

Перспективна орієнтованість індивідуального досвіду особистості показала також ряд відмінностей між вибірками.

Встановлено, що види рефлексивних процесів визначають зміст узагальненого образу Я за ознаками комунікативних, матеріальних та персонально-рефлексивних якостей особистості $(\mathrm{p} \leq 0,05)$. Окрім того, частотний аналіз показав повноцінне наповнення усіма категоріальними ознаками бажаного образу Я особами, які мають сформовану лише системну (позитивну) рефлексію. Більш-менш різноплановим є образ Я і у осіб, які окрім системної рефлексії мають сформовані й інтроспективні рефлексивні процеси. А от комбінація позитивної (системної) рефлексії і квазірефлексії значно звужує бажаний образ себе. Такі досліджувані, самопроектуючись, ставлять завдання на розвиток переважно комунікативних, фізичних та діяльнісно-професійних яко- 
стей. Найменше їх цікавлять власні соціальні, матеріальні та персонально-рефлексивні характеристики. Відсутність сформованої позитивної рефлексії призводить до глибокого самокопання i, можливо, самозвинувачення, на що вказує той факт, що всі без виключення досліджувані, у яких сформовані лише негативні рефлексивні процеси, у бажаному образі Я виділяють персонально-рефлексивні характеристики. Відзначають вони також у проекті себе власні бажані соціальні, комунікативні та фізичні якості. Особи, у яких не сформовані ніякі рефлексивні процеси, мають найвужчий за наповненістю проект власної особистості. Вони бажають розвиватися лише у соціальному та персонально-рефлексивному напрямах.

Таким чином, особливості сформованих рефлексивних процесів значно впливають на проектування власної особистості. Лише системна (позитивна) рефлексія дозволяє враховувати всі надані суспільством можливості для саморозвитку. Сформовані квазірефлексивні процеси, за яких ситуація досить часто оцінюється не об'єктивно, а спотворено, блокують різнопланові напрями розвитку особистості. Відсутність сформованих рефлексивних процесів, можна допустити, блокує взагалі весь процес самопроектування особистості, оскільки бажаними якостями вказуються лише соціальні та персональні, які пропагуються у сучасному культурному просторі.

Статистика також показала значимі відмінності у відсутності зразку для наслідуван- ня при самопроектуванні особистості залежно від сформованих рефлексивних процесів ( $\mathrm{p} \leq 0,05)$. За результатами статистичного та частотного аналізів можна зробити наступні висновки: сформовані негативні рефлексивні процеси, переважно інтроспективна рефлексія, ускладнюють процес самопроектування особистості установкою на неможливість досягнення певних взірцевих прикладів, з одного боку, та не сприяють створенню з врахуванням власних життєвих смислів збірного орієнтиру саморозвитку, з іншого; сформовані негативні рефлексивні процеси, переважно квазірефлексія, та відсутність сформованих жодних видів рефлексій унеможливлюють створення ідеалізованого зразку для наслідування з урахуванням власного життєвого досвіду, тобто блокують смислотворчі процеси у самопроектуванні особистості; при сформованій лише системній (позитивній) рефлексії у самопроективній діяльності завжди $є$ певний взірець прагнення, який здебільшого (75 \%) формується у результаті смислотворення на основі розуміння та інтерпретації власного життєвого досвіду.

Значимих статистичних відмінностей за передбаченням того чи іншого типу перепон на шляху до бажаної особистості у різновидах рефлексивних процесів не виявлено. Але у частотному співставленні даних помітно, що у комбінаціях позитивної рефлексії 3 негативними рефлексивними процесами та при лише негативних рефлексивних процесах 
більше уваги приділяється перепонам внутрішнього характеру. При сформованій лише позитивній рефлексії, у порівнянні з вищеописаними комбінаціями, перепонам внутрішнього характеру приділяється дещо менше уваги, а зовнішнього - більше. При несформованій рефлексії тим та іншим перепонам уваги приділяється приблизно порівну. За поміченою тенденцією можемо припустити, що системна рефлексія сприяє спрямуванню життєвої активності особистості на подолання об'єктивних завад на шляху власного саморозвитку.

За наявними ресурсами, що сприяють втіленню проекту особистості, у осіб з різними видами рефлексивних процесів також статистично достовірних відмінностей не встановлено. Всі досліджувані відзначають певні ресурси власного самоздійснення. Варто лише зазначити, що всі без виключення досліджувані (100\%), у яких не сформована рефлексія, ресурси шукають у власних характерологічних та особистісних можливостях, менше враховуючи об'єктивні сприятливі обставини та менше отримуючи зовнішню підтримку.

Статистичний аналіз також дозволив встановити що, у осіб з несформованою рефлексією не має чіткої диференціації соціальних і комунікативних особистих якостей та звужуються можливості у застосуванні сприятливих умов для самовдосконалення, зокрема блокується процес прийняття допомоги від зовнішнього оточення. Респонденти зі сформованою системною рефлексією передбача- ють найбільшу різноплановість особистих якостей за визначеними на сьогодні цілями саморозвитку. Вважаємо, що виявлений факт вказує на передбачення більш далекої перспективи саморозвитку.

Отже, різні види рефлексивних процесів здійснюють різноплановий вплив на самопроектування особистості, який не завжди сприяє розгортанню цього процесу.

Володіння позитивною (системною) рефлексією дозволяє особистості враховувати всі надані суспільством можливості для саморозвитку та проектувати різнобічний образ власного Я. Особистість, яка має сформовану позитивну рефлексію, у власному саморозвитку завжди орієнтується на певний взірець, який здебільшого формується у результаті смислотворення на основі розуміння та інтерпретації власного життєвого та соціокультурного досвіду. За базис подальшого особистого самопроектування та розвитку такі особи обирають власні наявні комунікативні, діяльнісно-професійні та персонально-рефлексивні якості, які є більш індивідуалізованими та активують процес саморозвитку особистості. Позитивна рефлексія сприяє спрямуванню життєвої активності особистості на подолання об'єктивних завад на шляху власного саморозвитку та забезпечує передбачення більш далекої перспективи саморозвитку.

Особи із сформованими негативними видами рефлексії більше за інших в успіху саморозвитку сподіваються на зовнішні обста- 
вини, випадок, підтримку та найменше проявляють суб'єктну активність у самоздійсненні, втрачаючи авторство в автопроекті.

Квазірефлексивні процеси унеможливлюють створення ідеалізованого зразку для наслідування 3 урахуванням власного життевого досвіду, тобто блокують смислотворчі процеси у самопроектуванні особистості, а також блокують різнопланові напрями розвитку особистості, задаючи іiі розвитку певний вектор.

Інтроспективна рефлексія ускладнює процес самопроектування особистості установкою на неможливість досягнення певних взірцевих прикладів відомих особистостей, з одного боку, та не сприяє створенню власного смислотворчого орієнтиру саморозвитку, 3 іншого, а також, за рахунок глибокого «самокопання» блокує визнання власних особистісних переваг, i, як наслідок, провокує неприйняття свого наявного образу Я.

Відсутність сформованих рефлексивних процесів блокує авторство процесу самопроектування особистості, оскільки бажаними, а також і базовими якостями виступають соціальні та персональні характеристики, які пропагуються у сучасному соціокультурному просторі. При несформованій рефлексії простежується відсутність чіткої диференціації соціальних та комунікативних особистих якостей. У процесі самоздійснення такі особи здебільшого покладаються на власні характерологічні та особистісні можливості, майже не враховуючи об'єктивні обставини, а також вони не схильні приймати допомогу від близьких та іншого зовнішнього оточення.

У цілому, визначення особливостей формування рефлексивних процесів у самопроектуванні особистості показало, що несформованість системної (позитивної) рефлексії $\epsilon$ блокуючою умовою для самопроектування особистості. Втім, комбінації позитивної рефлексії 3 певним видом негативної (інтроспективної та квазірефлексії) також мають несприятливий вплив на формування автопроекту. Причому, якщо комбінація позитивної рефлексії з квазірефлексивними процесами має виключно блокуючий вплив на процес самопроектування особистості, то інтроспективна рефлексія не завжди. У деяких випадках інтроспективна рефлексія сприяє актуалізації особистого самопроектування.

Отже, названа авторами диференційної моделі рефлективності інтроспекція «негативною» не завжди чинить лише блокуючий вплив на самопроектування та саморозвиток особистості.

У результаті проведеного дослідження можна виділити визначені рефлексивні стилі особистості за критерієм спонукального чи блокувального їх впливу на розвиток здатності до самопроектування особистості:

Конструктивний рефлексивний стиль, що має актуалізуючий, спонукальний вплив на розвиток здатності до самопроектування (відзначений у вибірках «позитивна рефлек- 
сія» та «позитивна + інтроспекція»).

Неконструктивний рефлексивний стиль має переважно блокувальний вплив на розвиток здатності до самопроектування особистості та розподіляється на два підвиди:

Iз включеними квазірефлексивними процесами, які відзначено у вибірках «усі види рефлексії» та «позитивна + квазірефлексія»;

Із несформованою позитивною рефлексією, що відзначена у вибірках «негативна рефлексія» та «несформована рефлексія».

Головні висновки. Дослідження особливостей різновидів рефлексивних процесів у здатності особистості до самопроектування дозволило встановити, що несформованість позитивної (системної) рефлексії є умовою, що блокує процес розвитку здатності до самопроектування особистості. Втім, комбінації позитивної рефлексії з певним видом негативної (інтроспективної та квазірефлексії) також можуть мати несприятливий вплив на формування автопроекту. Причому, якщо комбінація позитивної рефлексії 3 квазірефлексивними процесами має виключно блокувальний вплив, то інтроспективна рефлексія не завжди. У деяких випадках інтроспективна рефлексія сприяє актуалізації особистого самопроектування.

За результатами аналізу спонукальних і блокувальних впливів різновидів рефлексивних процесів на розвиток здатності до самопроектування особистості виділено однин конструктивний та два неконструктивні рефлексивні стилі особистості.

\section{Перспективи використання резуль-} татів дослідження полягають у створенні розвивального середовища, яке було б спрямованим на стимулювання розвитку конструктивного рефлексивного стилю особистості.

\section{Перелік використаних джерел:}

1. Леонтьев Д. А. Рефлексия «хорошая» и «дурная»: от объяснительной модели к дифференциальной диагностике / Д. А. Леонтьев, Е. Н. Осин // Психология. Журнал Высшей школы экономики. - 2014. - Т. 11. - С. 110-135. - Режим доступу : https://psyjournal.hse.ru/2014-11-4/141399859.html.

2. Самопроектування особистості у дискурсивному просторі: монографія [Електронний ресурс] / Н. В. Чепелєва, М. Л. Смульсон, О. В. Зазимко, С. Ю. Гуцол [та ін.] ; за ред. Н. В. Чепелєвої. - К. : Педагогічна думка, 2016. - 233 с. - Режим доступу : http:// lib.iitta.gov.ua/704560/.

3. Тищенко П. Д. «Дано мне тело...» / П. Д. Тищенко // Человек. - 1990. - № 3. - С. 41-49.

\section{References (Transliteration):}

1. Leontev D. A., Osin E.N. Refleksija «horoshaja» i «durnaja»: ot ob'jasnitelnoj modeli k differencialnoy diagnostike // Psihologija. Zhurnal Vysshey shkolyi ekonomiki. - 2014. - T. 11. - S. 110-135. - Retrieved from https://psyjournal.hse.ru/2014-11-4/141399859.html.

2. Samoproektuvannya osobystosti u dyskursyvnomu prostori: monohrafiya / N. V. Chepelyeva, M. L. Smulson, O. V. Zazymko, S. Yu. Hucol [ta in.] ; za red. N. V. Chepelyevoyi. - K. : Pedahohichna dumka, 2016. 233 s.- Retrieved from http://lib.iitta.gov.ua/704560/ 
3. Tishhenko P. D. «Dano mne telo...»/ P. D. Tishhenko // Chelovek. - 1990. - \# 3. - S. 41-49.

\section{Koliarova Anastasiia}

PhD student of H. S. Kostyuk Institute of Psychology of the National Academy of Educational Sciences of Ukraine, Kyiv (Ukraine)

\section{SPECIFIC ASPECTS OF REFLECTIVE PROCESSES OF PERSONALITIES WITH DIVERSE BODILY EXPERIENCE IN THE CONTEXT OF SELF-DESIGNING}

\section{ABSTRACT}

The article describes the results of the empirical study of the specific aspects of diversity of reflective processes of the personalities, who in certain life circumstances (professional, motivational, state of health) acquired bodily experience, in their ability for self-designing of personality.

The conducted empirical study and interpretation of its results are based on theoretical and methodological principles of psychological and hermeneutical approach.

Analysis of the scientific literature on the subject of the study enabled to determine specific aspects of forming the bodily experience and developing the study methodology. The ability for self-designing of a personality is considered to be a complex multilevel construction whose core component is an integral body of psychological characteristics of a personality, among which the following are determined: self-conception that is based on self-knowledge, self-awareness and selfidentification; subjective control as a personality self-determinacy indicator; life-purpose orienta- tions as a result of purpose-creation and lifecreation of a personality; prospective directivity of individual experience of a personality. Appropriate reliable and valid psychodiagnostic techniques were selected for each of the determined factors. Types of reflective processes were detected by means of a reflexivity differential diagnostics technique (D. Leontyev, 2014).

The study was conducted on empirically formed samples characterized by various combinations of the existing forms of reflection: "positive reflection"; "all kinds of reflection"; "positive + introspection"; "positive + quasireflexion"; "negative reflection"; "unformed reflection". The ascertainment of intergroup distinctions was conducted by means of realization of statistical Mann-Whitney U-test with paired comparison of all six samples. The statistically defined distinctions based on the findings of the self-conception study enabled to characterize special aspects of samples with diverse reflective processes.

According to the results of the analysis of the motivational and blocking influences of the diversity of reflective processes on the development of the ability for self-designing of a personality, one constructive and two non-constructive reflective personality styles are singled out.

The constructive reflective style is distinguished in the samples "positive reflection" and "positive + introspection". Non-constructive reflective styles block the process of development of the ability for self-designing of a personality 
and have two subspecies: non-constructive reflective style with included quasi-reflective processes (noted in the samples "all kinds of reflections" and "positive + quasi-reflexion"); nonconstructive reflective style with unformed positive reflection (noted in the samples "negative reflection" and "unformed reflection"). Prospects for using the results of the study call for the creation of the enriching environment aimed at developing a constructive reflective personality style.

Key words: reflective processes, reflective personality style, constructive reflective style, non-constructive reflective styles, bodily experience, ability for self-designing of personality.

\section{Колярова Анастасия Олеговна}

Аспирант Института психологии имени Г. С. Костюка Начиональной академии педагогических наук Украинь, г. Киев (Украина)

\section{ОСОБЕННОСТИ РЕФЛЕКСИВНЫХ ПРОЦЕССОВ ЛИЦ С РАЗЛИЧНЫМ ТЕЛЕСНЫМ ОПЫТОМ В КОНТЕКСТЕ САМОПРОЕКТИРОВАНИЯ}

Аннотация. В статье описаны результаты эмпирического исследования особенностей различных видов рефлексивных процессов лиц, которые при определенных жизненных обстоятельствах (профессиональных, мотивационных, состоянии здоровья) получили телесный опыт, в контексте развития их способности к самопроектированию личности. Проведенное эмпирическое исследование и интерпретация его результатов базируются на теоретико-методологических положениях пси- холого-герменевтического подхода.

Анализ научной литературы по теме исследования позволил определить особенности формирования телесного опыта и разработать методику исследования. Способность личности к самопроектированию рассматривается как сложное многоуровневое образование, ядерной составляющей которого является интегральный корпус психологических характеристик личности, среди которых определяются следующие: самоотношение, что основывается на самопознании, осмыслении и самоопределении; субъективный контроль как показатель уровня самодетерминованости личности; смысложизненные ориентации как результат смыслообразования и жизнетворчества личности; перспективная ориентированость индивидуального опыта личности. Для каждого из определенных факторов подобрано соответствующие надежные и валидные психодиагностические методики. Виды рефлексивных процессов выявлено с помощью методики дифференциальной диагностики рефлексивности (Д. Леонтьев, 2014).

Исследование проведено на эмпирически сформированных выборках, для которых характерны различные комбинации сложившихся видов рефлексии: «позитивная рефлексия»; «все виды рефлексии»; «положительная + интроспекция»; «положительная + квазирефлексия»; «негативная рефлексия»; «сформированная рефлексия». Установление межгрупповых раз- 
личий проведено посредством реализации статистического теста U - критерия МаннаУитни при попарном сравнении всех шести выборок. Статистически определенные различия по результатам исследования самоотношения позволили охарактеризовать особенности выборок с различными рефлексивными процессами.

По результатам анализа активизирующих и блокирующих воздействий разновидностей рефлексивных процессов на развитие способности к самопроектированию личности выделен один конструктивный и два неконструктивные рефлексивные стили личности. Конструктивный рефлексивный стиль отмечен в выборках «позитивная рефлексия» и «положительная + интроспекция». Неконструктивные рефлексивные стили блокируют процесс развития способности к самопроектированию личности и имеют два подвида: неконструктивный рефлексивный стиль с включенными квазирефлексивными процессами (отмечен в выборках «все виды рефлексии» и «положительная + квазирефлексия»); неконструктивный рефлексивный стиль с несформированной положительной рефлексией (отмечен в выборках «негативная рефлексия» и «несформированная рефлексия»). Перспективы использования результатов исследования предусматриваются в создании развиваю- щей среды, направленной на развитие конструктивного рефлексивного стиля личности.

Ключевые слова: рефлексивные процессы, рефлексивный стиль личности, конструктивный рефлексивный стиль, неконструктивные рефлексивные стили, телесный опыт, самопроектирование личности, способность к самопроектированию личности.

Дата отримання статті: 14.06 .2018 Дата рекомендації до друку: 24.06.2018 Дата оприлюднення: 02.07.2018 